\title{
Impact of Density Degree and Grade of Inorganic Binder on Behavior of Molding Sand at High Temperature
}

\author{
Mateusz Stachowicz ${ }^{a *}$, Patrycja Paduchowicz ${ }^{\mathrm{a}}$, Kazimierz Granat ${ }^{\mathrm{a}}$ \\ a Wroclaw University of Science and Technology, Department of Foundry, Plastics, and Automation, Łukasiewicza 7-9, 50-371 Wroclaw, \\ Poland \\ "e-mail: mateusz.stachowicz@pwr.edu.pl
}

Received: 8 August 2017/Accepted: 16 October 2017/Published online: 9 November 2017

This article is published with open access at AGH University of Science and Technology

\begin{abstract}
This paper discusses the impact of high temperatures (up to $900^{\circ} \mathrm{C}$ ) on molding and core sand with inorganic binders selected from among the group of unmodified grades of hydrated sodium silicate (water-glass). Molding sands with medium quartz sand were made under laboratory conditions and compacted at the different energy inputs necessary for obtaining various apparent densities $\left(\mathrm{Q}_{0}\right)$. Due to the different composition and apparent density of molding mixtures hardened via microwaves at a frequency of $2.45 \mathrm{GHz}$, it was possible to assess their deformation $(L)$ at a high temperature above the binder's eutectic temperature. For this purpose, an apparatus for hot distortion tests was used whose construction and equipment allows us to measure the thermoplastic deformations in molding sand in many aspects; i.e., in its time of annealing. The article proposes new possibilities of interpreting the hot distortion phenomena in comparative studies of molding materials and mixtures. The application of this new measurement method revealed the differences between molding mixtures made with five inorganic binders with a molar module ranging from 2.0 to 3.4 and apparent density ranging from 1.34 to $1.57 \mathrm{~g} / \mathrm{cm}^{3}$. It was established that distortions under the influence of high temperatures last the longest in molding sand with a binder with the highest molar module (3.4). Research also revealed that the density of molding sand is significant for increasing/decreasing the rate of thermoplastic deformations following the heating of samples only if the molding sand includes binders with a molar module of between 3.0 to 3.4. For molding sand with binders with molar modules from 2.0 to 2.5 , it was established that this is excessively susceptible to thermoplastic deformation.
\end{abstract}

\section{Keywords:}

foundry, hydrated sodium silicate, hot-distortion, thermal deformation, molding sands

\section{INTRODUCTION}

If properly manufactured, casts should have the least-possible number of casting faults. It is expected that casts should be cost-effective and environmentally friendly. For the best effects, it is essential to select the proper composition of molding sand and correctly manufacture the mold and core [1, 2]. The new molding materials offered on the market at present are becoming better and better, as their quality and properties meet the strictest requirements. However, the requirements cannot guarantee that the casts are made without defects. The selection of an appropriate binder considerably affects the resistance of molding sand to jets of liquid metal. Research [3,4] carried out with the use of binding materials like furan resins and water-glass demonstrated that it is more effective to use inorganic binders than organic ones. The technology of manufacturing molding and core sands and the molding parameters are also of importance. Among the reasons behind casting faults are the improper density of molding sand and the failure to adjust this parameter to the process of pouring and solidifying the casting alloy [1-4].
Quoting [5], the density degree of molding sand is a parameter dependent on the material properties and initial density degree. Proper distribution of density in the mold or core is affected by external and internal friction and elastic deformation at high temperature, among others. They may cause some resistance when a part is pulled out of the mold, which may in turn bring about deformations inside the mold cavity. The proper density of molding sand (which can also be expressed by another parameter - apparent density) ensures the required surface smoothness and casting dimension tolerance. In the process of densifying by pressing, for example, molding sand should be liquid to such an extent that it allows free movement from the areas of greater mold density to areas of smaller density [2].

If the density of molding sand increases, a greater shear force is needed to move the neighboring layers (which is particularly important and even desired for the manufacturing of casting cores); however, this eventually reduces casting surface roughness. The density degree of the molding sand and the shape and size of the matrix grains exert a considerable influence on mold or core permeability [6]. 
If, however, the density of the molding sand is improper and too low, it leads to the erosion of the mold surface layers and may bring about friability. The extent of wear detected in molding sand, including that with water-glass [7], depends on the angle of the liquid metal jets on the wall of the mold cavity as well as its temperature, dynamics, and pouring time. The defects caused by the insufficient density of molding sand include sand contamination and liquid metal penetration into the pores of the molding sand, lowering the casting surface quality. As a result of the excessive deformations inside the mold cavity, shape defects and burns occur $[7,8]$. In order to eliminate such faults, protective coatings are applied [9-11]; however, this prolongs the time of mold preparation and impedes the process of matrix regeneration. The application of popular alcohol-based coatings has a negative effect on the environment due to the fact that, when the mold is dried before pouring, dangerous vapors and gases are released.

In molding sand with hydrated sodium silicate (waterglass), mold erosion is less intensive that in molding sand with organic binders; however, the area affected by the erosion is greater $[7,8]$. Therefore, for this type of molding sand, it becomes necessary to use protective coatings in order to reduce corrosion pits and burns [4]. The coating thickness is also worth mentioning. Study [8] shows that, in the case of coatings applied on molding sand with waterglass, the thickness of the layer is of particular importance. Moreover, the casting quality largely depends on the phenomena that take place in the mold at the time liquid metal is poured into it (when the temperature is at its highest level). Then, thermal and mechanical deformations occur that affect the dimensional accuracy and casting surface smoothness.

Therefore, interesting from the point of cast quality is the identification of all phenomena associated with the impact of liquid metal on the elements of the casting mold cavity.

Helpful are tests based on a broadly understood analysis called "thermal" or "hot" distortion [11-13]. However, at the moment of writing the article, this method is not standardized nor determined by the relevant standards. As a result of the non-standardized measuring method, researchers are able to use a "hot-" or "thermal-" distortion apparatus to study the phenomena of deformation for various purposes as well as introduce them by their modifications and improvements, like in the DMA Hot Distortion Tester [11], Hot Distortion Plus $®$ [14] method, or Hot Distortion Tester for the samples sized $5.24 \times 2.54 \times 1.27 \mathrm{~cm}$ described in [15].
As opposed to the common analyses determining whether a given type of molding sand can be used in a production process, hot distortion tests (HDT) take into consideration not only the strength properties but also the thermal phenomena that largely influence the final casting shape, dimensional accuracy, and smoothness. During the pouring of the liquid metal into the mold, the alloy contact and intensively heats the mold cavity walls. As a result of the high temperature and mechanical stress, negative phenomena occur in the molding sand: thermal deformation, thermal and mechanical destruction, and thermoplasticity. These may damage the mold or core structure, which depend on the molding mixture components [11-17]. The extent of the distortions that emerged during the pouring of the liquid metal may be modified by means of special plasticizers added to the binders. These enhance the elasticity of the molding and core sand. Previous studies have confirmed the positive influence of collagen plus alkali silicate [15] on the properties of molding sand or polycaprolactone [18] on the properties of molding sand with phenol-furfural resin. Another method for improving the strength properties of molding sand at high temperatures consists of applying coatings on the cores. The effectiveness of these methods is confirmed by hot distortion analyses made for cores with a hydrated sodium silicate [19].

The strength of physically cured molding sand with hydrated sodium silicate at an ambient temperature is higher than that of bentonite molds and comparable $[20,21]$ to molding sand with organic binders. However, the pouring of liquid metal causes greater damage in molding sand with hydrated sodium silicate as the binder $[7,22]$. In order to explain this phenomenon, it seems the analyses of molding sands at high temperatures will be of key importance.

\section{RESEARCH METHODOLOGY}

The molding sand used for the purposes of this study was made of dried medium quartz sand with a grain size of 1K 0.20/0.315/0.16 (according to norm PN-85/H-11001) from a Polish mine (Grudzeń Las) and five unmodified grades of hydrated sodium silicate produced in a chemical plant called 'Rudniki' S.A. (Tab. 1). Each time, 1 kg of molding sand was prepared by means of a planetary mixer: to 100 weight parts of the matrix, 0.5 weight parts of water were added [21]; then, after $60 \mathrm{~s}$ of mixing, 1.5 weight parts of the selected binder were added and mixed for $180 \mathrm{~s}$.

Table 1

Physico-chemical properties of five grades of hydrated sodium silicates used for preparation of molding sands

\begin{tabular}{|c|c|c|c|c|c|}
\hline $\begin{array}{l}\text { Grade of hydrated } \\
\text { sodium silicate/ } \\
\text { Type of molding sand }\end{array}$ & $\begin{array}{l}\text { Molar module } \\
\left(\mathrm{SiO}_{2} / \mathrm{Na}_{2} \mathrm{O}\right)\end{array}$ & $\begin{array}{l}\text { Oxide contents } \\
\left(\mathrm{SiO}_{2}+\mathrm{Na}_{2} \mathrm{O}\right) \\
\text { min.\% }\end{array}$ & $\begin{array}{c}\text { Measured } \\
\text { oxide contents } \\
\left(\mathrm{SiO}_{2}+\mathrm{Na}_{2} \mathrm{O}\right) \\
\%\end{array}$ & $\begin{array}{l}\text { Measured den- } \\
\text { sity }\left(20^{\circ} \mathrm{C}\right) \\
\mathrm{g} / \mathrm{cm}^{3}\end{array}$ & $\begin{array}{c}\text { Absolute } \\
\text { viscosity min., } \\
\text { P }\end{array}$ \\
\hline 137 / MS137 & 3.4 & 35.0 & 36.3 & 1.37 & 1 \\
\hline 140 / MS140 & 3.0 & 36.0 & 39.4 & 1.42 & 1 \\
\hline 149 / MS149 & 2.9 & 42.5 & 44.3 & 1.51 & 7 \\
\hline 145 / MS145 & 2.5 & 39.0 & 41.5 & 1.47 & 1 \\
\hline 150 / MS150 & 2.0 & 40.0 & 43.5 & 1.52 & 1 \\
\hline
\end{tabular}


The samples with the dimensions of $120 \times 25 \times 6 \mathrm{~mm}$ $(l \times b \times h)$ to be investigated in terms of distortions at higher temperatures were compacted by means of an LU-1 laboratory rammer. A weight of $6.667 \mathrm{~kg}$ was dropped a different number of times from a fall height of $50.3 \mathrm{~mm}$ in order to obtain various density. In this research, the samples were compacted two (II), three (III), or five times (V) using the rammer.

The molded samples were then hardened with electromagnetic waves of a frequency of $2.45 \mathrm{GHz}$ and power of $1000 \mathrm{~W}$ in the chamber of a microwave furnace by Plazmatronika (with a capacity of $32 \mathrm{dm}^{3}$ ) equipped with one magnetron and the load-rotation feature. The selected heating time of $240 \mathrm{~s}$ regardless of the various density degrees of the samples (ranging from 1.05 to $1.40 \mathrm{~g} / \mathrm{cm}^{3}$ ) ensured the effective dehydration of the molding sand in its whole volume [23]. The analyses started from a mass stabilization to the nearest $0.01 \mathrm{~g}$ by means of an Ohaus PA4102CM/1 scale. The density degree was expressed as the apparent density $\left(\varrho_{0}\right)$; i.e., as the ratio of the mass of each sample after curing and cooling-down to the volume calculated on the basis of its dimensions. For the purposes of the hot distortion test (HDT), a DMA apparatus made by Polish company Multiserw-Morek was used for examining the high temperature phenomena in molding sand. This HDT device [24] has two ceramic heaters and a max. temperature of heating ca. $990^{\circ} \mathrm{C}$ measured by K-type thermocouples.

The sample is placed in a special support and heated conventionally from two sides in its middle part (see Fig. 1). Thermal energy from both ceramic heating elements increases the environment temperature up to ca. $900^{\circ} \mathrm{C}$, causing distortion.

On the free end of the fitting, a sensor is placed that registers any changes in the sample location against time during annealing at ca. $900^{\circ} \mathrm{C}$. Depending on the grades of the molding sand and binder, the phenomenon of molding sand thermoplasticity occurs or not. Usually, deformation occurs in the direction of the applied load and the sensor located at the end of the sample (Fig. 1).

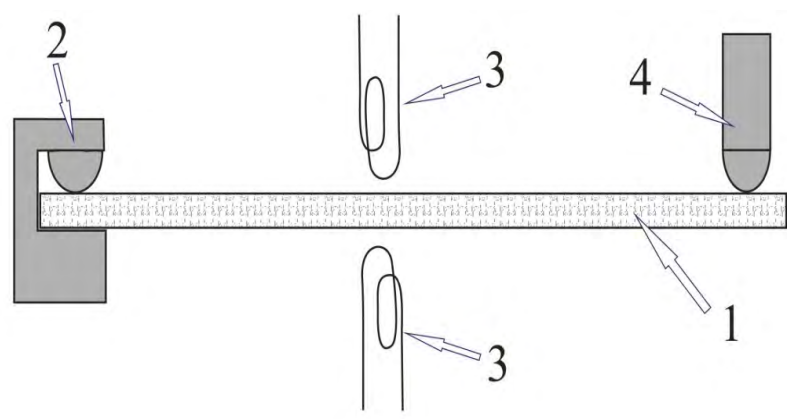

Fig. 1. Diagram of thermal deformation measuring stand 1) sample of molding sand; 2) support with grip; 3) heaters; 4) load (sensor) [24]

An annealing temperature set at $900^{\circ} \mathrm{C} \pm 10^{\circ} \mathrm{C}$ is above the temperature of phase transitions $[25,26]$ observed for commercial grades of sodium silicate. In previous studies [27], an unfavorable flow of the melted binder was observed at temperatures above $750^{\circ} \mathrm{C}$.
This study attempts to explain the phenomenon of the increased erosion of sodium silicate molding sands due to the effect of metal poured into cavity.

\section{RESULTS}

The first value under investigation was the average apparent density expressed in $\mathrm{g} / \mathrm{cm}^{3}$. The mass of the samples (cured and cooled for the purposes of the distortion tests) was compared to their capacity of $18 \mathrm{~cm}^{3}$; the results of which are demonstrated in Figure 2.

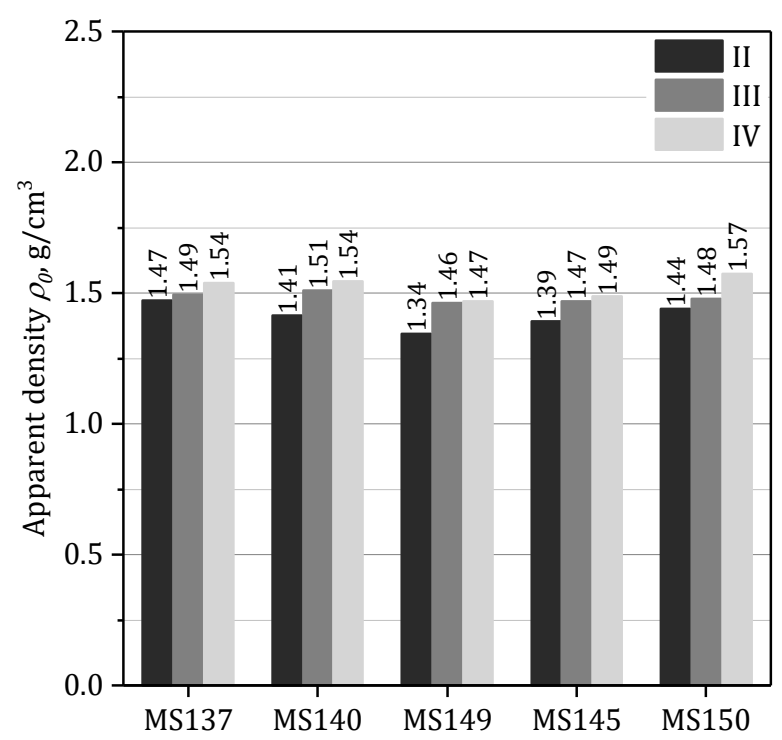

Fig. 2. Apparent density of cured molding sand with five grades of hydrated sodium silicate

The analysis reveals that the apparent density of the molding sand (MS137 - MS150) ranges from 1.34 to $1.57 \mathrm{~g} / \mathrm{cm}^{3}$ (Fig. 2). Due to the compacting method, it was feasible to differentiate between the apparent density of the molding sands with five grades of binders. As we know $[28,29]$, this is an important parameter for molding mixtures because of the interdependence between the increase/decrease in the apparent density of molding sand with a hydrated sodium silicate of $0.1 \mathrm{~g} / \mathrm{cm}^{3}$ and a constant (40\%) increase/decrease in their strength. Figures 3-7 show measurement graphs for the samples subjected to two-sided heating near the DMA elements heated up to $900^{\circ} \mathrm{C}$ (see Fig. 1).

Near the middle of the sample section, the ambient temperature in close proximity to the sample was recorded. An increase of $1^{\circ} \mathrm{C}$ set the beginning of deformation $(L)$ recording. Unfortunately, the originally adopted method of testing the deformation $(L)$ of the sample as a function of rising temperatures proved to be rather inaccurate. According to the indications of the environment temperature measuring element, the phase transition of the binder was already at $180-220^{\circ} \mathrm{C}$, which was not bserved in the research [25-27]. It was decided to present the results of thermal deformation as a function of time during the bothside heating of the samples (Figs. 3-7). 


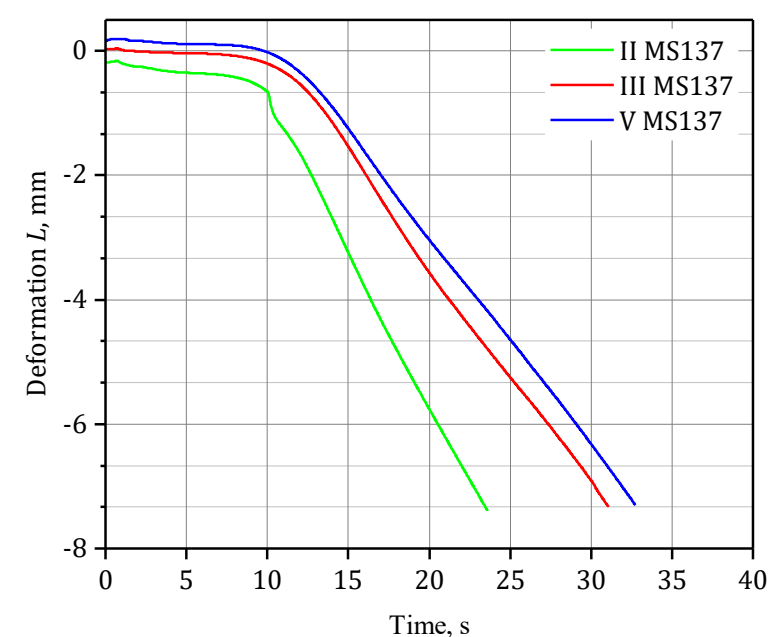

Fig. 3. Measurement results of hot distortion tests for molding sand with hydrated sodium silicate grade 137 densified two-, three-, or five-fold times

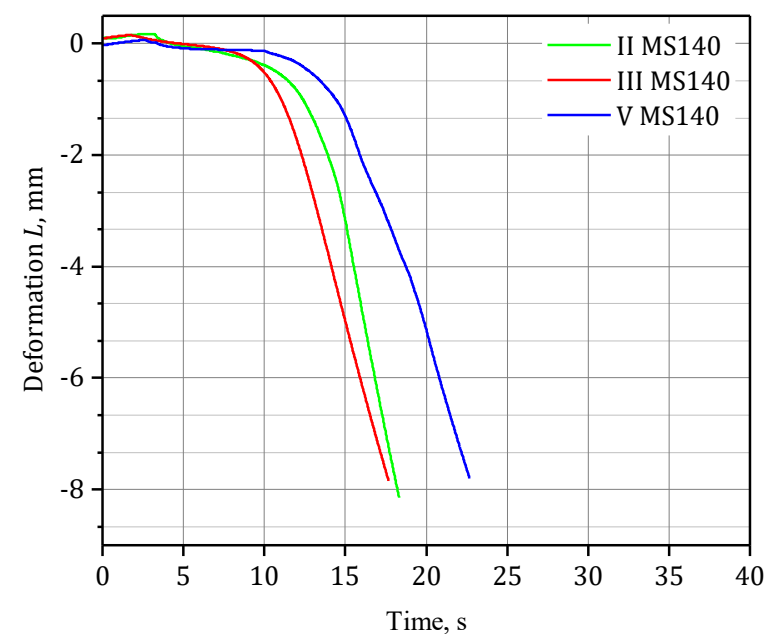

Fig. 4. Measurement results of hot distortion tests for molding sand with hydrated sodium silicate grade 140 densified two-, three-, or five-fold times

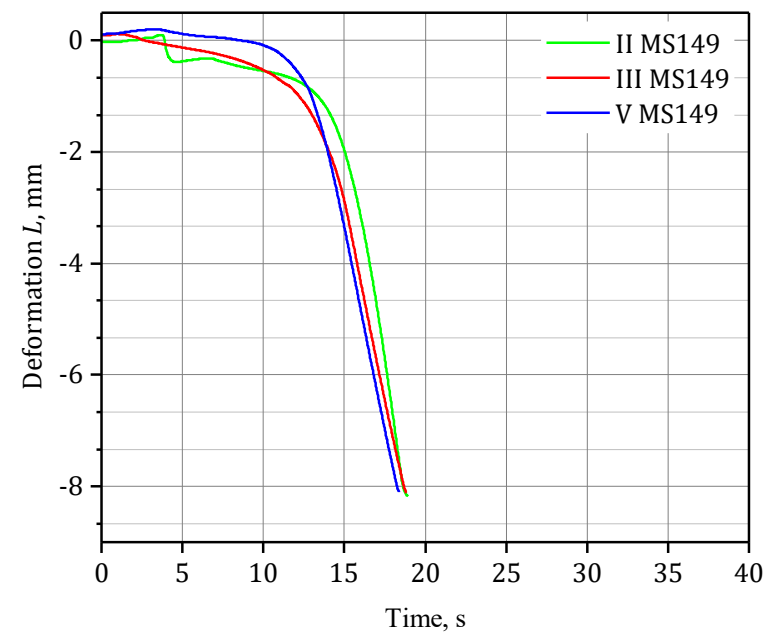

Fig. 5. Measurement results of hot distortion tests for molding sand with hydrated sodium silicate grade 149 densified two-, three-, or five-fold times

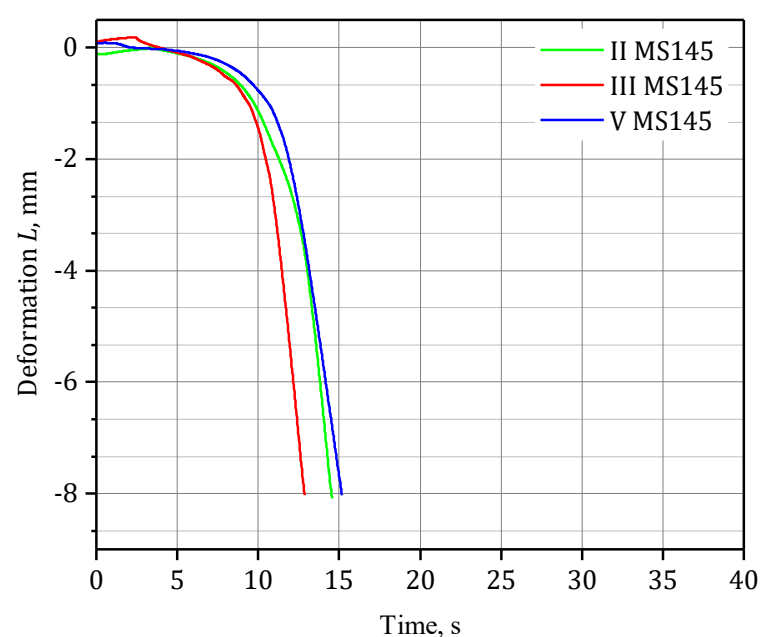

Fig. 6. Measurement results of hot distortion tests for molding sand with hydrated sodium silicate grade 145 densified two-, three-, or five-fold times

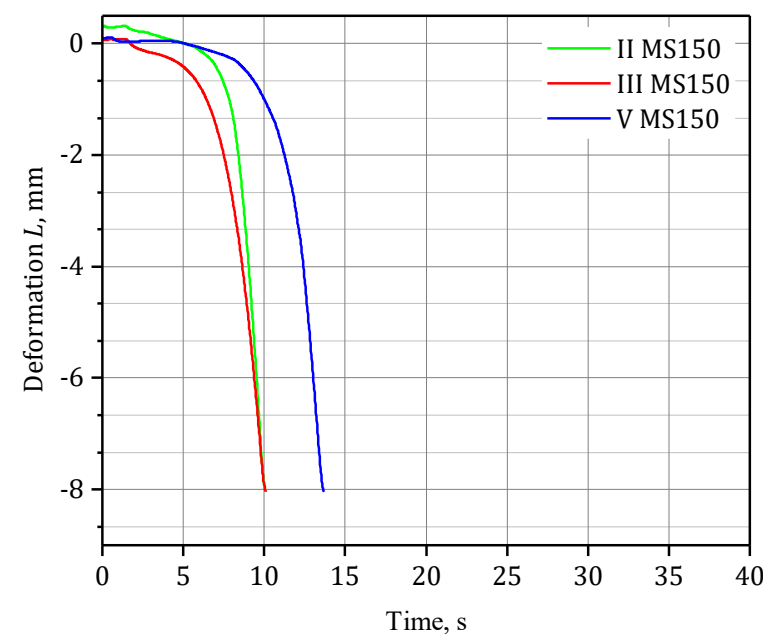

Fig. 7. Measurement results of hot distortion tests for molding sand with hydrated sodium silicate grade 150 densified two-, three-, or five-fold times

The analysis of distortion changes revealed that all types of molding sand with different grades of hydrated sodium silicate cured in an electromagnetic field have low heat expansion. After heating the samples on both sides, they became plasticized in a short amount of time. Each measurement was interrupted after the sample distortion exceeded $8 \mathrm{~mm}$. None of the samples was fractured during the heating process. It was established that the thermal deformations lasted the longest for the molding sand with a binder of a maximum molar module of 3.4 (Fig. 3).

In the case of this type of molding sand, the influence of a diversified apparent density on the speed with which the sample end moves under the weight of the sensor is also visible. Sample MS137 compacted five times to a density of $1.54 \mathrm{~g} / \mathrm{cm}^{3}$ (Fig. 3) showed the least thermoplasticity (the slope of the deformation curve to the time axis was the least). 
A similar phenomena of the slowing down of the process of molding sand plasticizing under the influence of high temperatures was detected for hydrated sodium silicate with a molar module of 3.0 - MS140 (see Fig. 4). The deformation graphs (Fig. 5) demonstrate a tendency similar to that for binders 137 and 140; i.e., a tendency to impede the process of plasticizing the molding sand with grade 149 hydrated sodium silicate. However, it was established that the thermal deformation is not sensitive to diversified density (Fig. 2) for this molding sand - MS149. The types of molding sand with the binders of grades 145 (Fig. 6) and 150 (Fig. 7) can be deemed as susceptible to excessive thermoplasticity on the basis of deformation changes, while the diversified apparent density of the molding sand exerted no influence on the rate of changes. The exception is MS150 with the highest measured apparent density $\left(1.57 \mathrm{~g} / \mathrm{cm}^{3}\right)$, in which the resulting density has a delayed process of sample plasticization. It should be noticed, however, that all types of molding sand had low contents of binders (1.5\%wt.), which may be of significance for the speed at which the bridges binding the matrix grains plasticize. When cooled down to the ambient temperature, all of the samples crumbled in the middle, which confirms findings $[22,27,30]$ from recent research into microwave heating used for the curing of molding sand with hydrated sodium silicate.

\section{CONCLUSION}

An analysis of the thermal deformation of molding sand with hydrated sodium silicate cured by means of microwave heating revealed that it is the grade (molar module) of the binder that is essential; moreover:

For the molding sand with binders of molar modules ranging from 3.0 to 3.4 (Fig. 3), thermal deformations lasted the longest. The study also proved that, for these binders, the density of the molding sand is essential for increasing/ decreasing the speed of thermoplastic deformation resulting from the heating of the samples.

For molding sand with a binder grade 149 and of a molar module of 2.9, a tendency to impede the process of plasticizing the molding sand was established (though the distortion is not affected by diversified density).

The most-common types of molding sand in the foundry industry (i.e., molding sands MS150 and MS145 with binders of molar modules from 2.0 to 2.5 [grades 150 and 145]) show excessive thermoplasticity.

The Multiserw-Morek DMA device allows us to adopt its basic HDT measurement functions for the precise comparative research of molding mixture behavior at high temperatures to reduce the negative effect of cavity erosion. The study proved that precise HDT measurements are possible while the temperature of the sample environment is well stabilized.

Further research should be carried out with a different content of binders containing hydrated sodium silicate and other physical and physico-chemical methods of curing in order to select the optimum environment-friendly technology of molding and core sand.

\section{Acknowledgements}

The research has been financially supported by the Wroclaw University of Technology with grants for statutory activity No. 0402/0165/16.

\section{REFERENCES}

[1] Lewandowski J.L. (1997). Tworzywa na formy odlewnicze. Kraków: Wydawnictwo Akapit.

[2] Szreniawski J. (1968). Piaskowe formy odlewnicze. Warszawa: Wydawnictwa Naukowo-Techniczne.

[3] Mocek J., Zych J., Chojecki A. (2004). Study of erosion phenomena in sand moulds poured with cast iron. International Journal of Cast Metals Research, 17(1), 47-50.

[4] Zych J., Mocek J. (2002). Zjawisko erozji w formach wykonywanych z mas ze spoiwami chemicznymi. Archives of Foundry, 2(3), 155-162.

[5] Biernacki R., Perzyk M., Kozłowski J. (2006). Modelowanie rozkładu stopnia zagęszczenia masy formierskiej z wykorzystaniem systemów uczących się. Archiwum Odlewnictwa, $6(18), 477-482$.

[6] Gierek A. (1968). Teoretyczne podstawy określania wielkości energii zagęszczania mas formierskich oraz jej wpływ na niektóre własności form odlewniczych. Mechanika, z. 33, Gliwice: Wydawnictwo Politechniki Śląskiej, zeszyt naukowy nr 215.

[7] Mocek J. (2003). Proces erozji form piaskowych ze spoiwem-szkłem wodnym. Archives of Foundry, 3(10), 23-30.

[8] Zych J., Mocek J. (2015). Destruction of moulding sands with chemical binders caused by the thermal radiation of liquid metal. Archives of Foundry Engineering, 15(4), 95-100.

[9] Jamrozowicz Ł., Zych J., Kolczyk J., Wróblewski D. (2014). Rola kształtu powierzchni formy w procesie wysychania wybranych powłok ochronnych. Archives of Foundry Engineering, 14 (spec. iss. 2), 39-44.

[10] Liu F.C., Fan Z.T., Liu X., Huang Y., Jiang P. (2016). Effect of surface coating strengthening on humidity resistance of sodium silicate bonded sand cured by microwave heating. Materials and Manufacturing Processes, 31(12), 1639-1642.

[11] Jakubski J., Dobosz S.M. (2007). The thermal deformation of core and moulding sands according to the hot distortion parameter investigations. Archives of Metallurgy and Materials, $7(52), 421-427$.

[12] Morgan D., Fashman E.W. (1975). The BCIRA hot distortion tester for quality in production of chemically bonded sands. AFS Transaction, 75(91), 73-80.

[13] Rodriguez J., Keil M., Ramrattan S., Krysiak M.B. (1998). Industry and academia collaboration for a thermal distortion tester for sand-binder systems. In: Proceedingsof the 1998 Annual Conference Seattle, Washington. American Society for Engineering Education.

[14] Ignaszak Z., Prunier J.B. (2013). Synergy of practical knowledge of moulding sands reclamation in heavy casting foundry of iron alloys. Archives of Foundry Engineering, 13(3), 30-36.

[15] Fox J.T., Cannon F.S., Brown N.R., Huang H., Furness J. (2012). Comparison of a new, green foundry binder with conventional foundry binders. International Journal of Adhesion \& Adhesives, 43, 38-45.

[16] Dobosz S.M., Gieniec A. (2002). Wpływ rodzaju osnowy na zjawiska wysokotemperaturowe $\mathrm{w}$ masach rdzeniowych. Archives of Foundry, 2(2), 33-38.

[17] Jakubski J., Dobosz S.M., Jelinek P. (2005). The influence of the protective coating type on thermal deformation of casting cores. Archives of Foundry, 5(5), 164-169.

[18] Major-Gabryś K., Grabarczyk A., Dobosz S.M., Drożyński D. (2016). Wpływ dodatku materiału biodegradowalnego jako komponentu dwuskładnikowego spoiwa odlewniczych mas formierskich i rdzeniowych na właściwości spoiwa oraz mas z jego zastosowaniem Prace Instytutu Odlewnictwa, 16(4), 391-399. 
[19] Wildhirt E., Jakubski J., Sapińska M., Sitko S. (2017). Impact of penetration depth of protective coating on thermal deformation of masses determined by the hot distortion parameter. Prace Instytutu Odlewnictwa, 56(1), 51-57.

[20] Jelinek P., Polzin H. (2003). Strukturuntersuchungen und Festigkeitseigenschaften von Natrium-Silikat-Bindern. Giesserei-Praxis, 2, 51-60.

[21] Stachowicz M., Granat K., Pałyga Ł. (2016). The effect of wetting agent on the parameters of dry moulding silica sands bonded with sodium water glass. Prace Instytutu Odlewnictwa, 56(1), 43-55.

[22] Stachowicz M., Granat K., Nowak D. (2011). Application of microwaves for innovative hardening of environment-friendly water-glass moulding sands used in manufacture of cast-steel castings. Archives of Civil and Mechanical Engineering, 11(1), 209-219.

[23] Stachowicz M. (2016). Effect of sand base grade and density of moulding sands with sodium silicate on effectiveness of absorbing microwaves. Archives of Foundry Engineering, 16(3), 103-108.

[24] DMA Hot-Distortion tester for bonded sands - Multiserw-Morek instruction manual 2017.
[25] Kracek F.C. (1930). The System Sodium Oxide-Silica. The Journal of Physical Chemistry, 34(7), 1583-1598.

[26] Ryś M. (2007). Investigation of Thermodynamic Properties of Alkali Metals in Oxide Systems Relevant to Coal Slags. Unpublished engineering thesis, Rheinisch-Westfälischen Technischen Hochschule Aachen, Aachen, Germany.

[27] Stachowicz M., Granat K., Nowak D. (2011). Influence of water-glass grade and quantity on residual strength of microwave-hardened moulding sands. Pt. 2. Archives of Foundry Engineering, 11(2), 143-148.

[28] Zych J. (2005). Rola zagęszczania w technologii formy opartej na masach ze szkłem wodnym i spoiwami organicznymi. Przegląd Odlewnictwa, 55(2), 88-97.

[29] Stachowicz M. (2017). The role of the densification of moulding sands with inorganic binders in the modeling of their strength obtained after microwave hardening. Prace Instytutu Odlewnictwa, 57(2), 103-113.

[30] Stachowicz M., Granat K., Nowak D. (2011). Influence of water-glass grade and quantity on residual strength of microwave-hardened moulding sands. Pt. 1. Archives of Foundry Engineering, 11(1), 93-98. 